\title{
Causes of the powerplants failures installed on Polish civil aviation aircraft
}

Currently in Poland about 2,500 different engine types are installed on the aircraft. In the years 2008-2016 powerplants failures caused nearly 600 aviation events. Aborted flight or emergency landing, especially in the case of aircraft powered by a single piston engine occurred. The objective of the article was to determine the failure causes and assessment of their impact on the flight safety. Engine faults were assigned to particular types of powerplants, for example turboshaft, piston, etc. Causes of the failures were examined, assigning ATA chapter to each of them. Also human factor was taken into account. According to the ICAO methodology, aviation safety engine systems essential for flight safety and theirs impact on the safety risk was determined. The results of the analyzes presented in this article are useful for managing the national aviation safety and supervising SMS in aviation organizations. The article shows that preventive measures to raise the level of aviation safety should be taken. This is the first comprehensive analysis of the powerplants failure causes and an evaluation of their influence on the level of aviation safety in Poland.

Key words: powerplant, aircraft engine failure, safety risk

\section{Introduction}

The hitherto operational experience indicate that to the greatest extent powerplant determines airplanes and helicopters safety of flying. Still significant number of aircraft engines exploitation is a subject of the guaranteed by manufacturers service life (so-called "hard time") [8, 9]. Such a time is usually determined by the manufacturers carrying out test-bed endurance programs where the engine is run day and night, cycling through a specified and purposely over-punishing schedule of so many hours at full power, so many at idle, so many at cruise. During the manufacturer's tests the engine is run on the test bed in a manner which is purposely more severe than ordinary operator will use. Often engines are tested in the flying beds as well as high altitude test-cells. During tests engine durability, especially resistance on uncontained failure of the fan, compressor and turbine cases are checked. Also resistance of the fan blades against bird strike is examined.

The hard time exploitation method requires technical inspections and engine overhaul conducting after its work for a certain period of time (regardless of the actual technical condition of the engine). After a guaranteed by manufacturer life the engine is subject of a cassation. The advantage of this method of operation is the possibility of a relatively simple overhaul and maintenance tasks planning, spare parts purchasing and new engines acquisition scheduling. This system, however, is expensive, because often unnecessary maintenance tasks have to be carried out, reduces aircraft operational readiness, requires removals of a serviceable engine parts (risk of damage during these works), in brief, increases engine direct maintenance cost.

It was noted that the degree of engine wear depends not only on the number of its working hours, but also on variety of difficult to evaluate factors like environmental conditions (eg. dust, salt, humidity), and aircraft flight profile. Also level of training and individual pilot psychophysical characteristics are engine condition influencers. An attempt to take into account the influence factors related to engine operating conditions was the use of appropriate statistical tools.
The development of a safe for aircraft application measurement and registration technologies, enabled introduction of the on-condition exploitation method applied for airframes, powerplants and specific aircraft parts. The possibility of obtaining reliable records of the registered parameters resulted, in turn, in the development of data interpretation methods. For the equipment reliability evaluation mathematical statistic methods in a wider range were applied $[5,7,11]$. The reliability function allows a determination of the system continued operation probability. The quality of the assessment depends on the obtained data credibility, samples volume, that is, from the experience gained during operation of a specific equipment type.

In order to present equipment reliability various indicators are used, which include inter alia time between failure, time between overhaul or factor describing the number of its failures per 1000 operating hours $[5,6,12]$.

The aircraft engines exploitation practice is to maintain the required level of the flight safety. For this purpose, in addition to the assessment of the engine's technical condition, identification of its installations significantly affect the flying safety is carried out. The risk associated with the frequency of their faults is determined, which is important one of the elements of aviation safety management system (SMS).

The identification of aircraft and engines systems was simplified by the introduction in 1956 standard numbering system ATA 100 developed by Air Transport Association (ATA) [4]. This rely on aircraft and engines systems description by giving them a two-digit number, eg. Chapter 73 - fuel supply and flow control, chapter 74 - ignition, chapter 80 - starting etc. This system has expanded in 1999 by adding two more digits to indicate each group, defining the specific subsystems, eg. in the chapter 71 - powerplant (general) separated: 7110 - cowling, 7120 - mounts, 7150 electrical harness etc. During the encoding of events caused by powerplant, recorded in the data base ECCAIRS as SCF-PP, the authors used the numbering system identical for large aircraft, small and helicopters. 


\section{Research methodology}

In order to analyse various types of the powerplants influence on flight safety, data contained in the ECCAIRS were reviewed. This database is conducted by SCAAI and ULC. Contains aviation event reports sent by the organizations involved in air operations. It is very extensive - contains over 7000 events in air traffic reported between 2008 and 2016. Reported aviation incidents are coded according to ICAO aviation occurrence categories [1,2].

Events caused by powerplants coded as SCF-PP were divided depending on engine type (piston, turboprop, turboshaft and turbine). As the number of Polish registered aircraft was changing between 2008 and 2016, factor in order to objectify the data analysis was introduced (equation 1).

$$
\mathrm{K}_{1000 \mathrm{TYPE}}=\frac{1000 \cdot \mathrm{LZ}_{\mathrm{TYPE}}}{\mathrm{LSP}_{\mathrm{TYPE}}}
$$

where: $\mathrm{LZ}_{\mathrm{TYPE}}$ - number of aviation events caused by turboshaft, turboprop, turbine and piston engines in certain year, $\mathrm{LSP}_{\mathrm{TYPE}}$ - number of registered aircraft powered by specified above type of engine in certain year.

Proper safety management lies not only in an identification of essential safety parameters and prediction of their level, but also requires an estimation of safety risk connected with selected safety indicators.

In order to assess safety risk, it is necessary to estimate the probability that the consequences of hazard will come to effect during aircraft operations. In literature five point probability table is frequently used [13]. The Tab. 1 includes five categories, which describe the probability related to an unsafe event.

Table 1. Safety risk probability [13]

\begin{tabular}{|l|c|c|}
\hline Likelihood & Meaning & Value \\
\hline Frequent & $\begin{array}{c}\text { Likely to occur many times } \\
\text { (has occurred frequently) }\end{array}$ & 5 \\
\hline Occasional & $\begin{array}{c}\text { Likely to occur sometimes } \\
\text { (has occurred inferequently) }\end{array}$ & 3 \\
\hline Remote & $\begin{array}{c}\text { Unlikely to occur, but possible } \\
\text { (has occurred rarely) }\end{array}$ & 2 \\
\hline Improbable & $\begin{array}{c}\text { Very unlikely to occur } \\
\text { (not known to have occurred) }\end{array}$ & 1 \\
\hline $\begin{array}{l}\text { Extremely } \\
\text { Improbable }\end{array}$ & $\begin{array}{c}\text { Almost inconceivable that the event will } \\
\text { occured }\end{array}$ & \multicolumn{1}{|c|}{} \\
\hline
\end{tabular}

The next step is a safety risk severity assessment, which is a potential harm that might occur as a consequence of the identified hazard. Tab. 2 from [13] has been utilized in order to evaluate safety risk as a consequence of a potential event caused by any powerplant system.

Based on the two tables above, safety risk assessment could be performed. Usually it is performed utilizing Tab.3 Safety risk assessment matrix, which is a combination of severity/probability

Events caused by particular type of powerplant system were assigned by authors and shown in the safety risk assessment tables (Tab. 5, Tab. 10, Tab. 13, Tab.16), which are presented in the chapters disscusing each engine type.
Table 2. Safety risk severity [13]

\begin{tabular}{|l|l|c|}
\hline Severity & \multicolumn{1}{|c|}{ Meaning } & Value \\
\hline Catastrophic & $\begin{array}{l}\text { Equipment destroyed } \\
\text { Multiple deaths }\end{array}$ & $\begin{array}{l}\text { A } \\
\text { Hazardous } \\
\text { physical distress or workload such that } \\
\text { the operators cannot be relied upon to } \\
\text { perform their tasks accurately or } \\
\text { completely } \\
\text { Serious injury } \\
\text { Major equipment damage }\end{array}$ \\
\hline Major & $\begin{array}{l}\text { A significant reduction in safety } \\
\text { margins, a reduction in the ability of the } \\
\text { operators to cope with adverse } \\
\text { operating conditions as a result of an } \\
\text { increase in workload, or as a result of } \\
\text { conditions impairing their efficiency } \\
\text { Serious incident } \\
\text { Injury to persons }\end{array}$ & C \\
\hline Minor & $\begin{array}{l}\text { Nuisance } \\
\text { Use of emergency procedures } \\
\text { Operating limitations } \\
\text { Minor incident }\end{array}$ & D \\
\hline Negligible & $\begin{array}{l}\text { Little consequences } \\
\text { E }\end{array}$ & E \\
\hline
\end{tabular}

Table 3. Safety risk assessment matrix [13]

\begin{tabular}{|c|c|c|c|c|c|c|}
\hline \multirow[b]{2}{*}{$\begin{array}{l}\text { Risk } \\
\text { probability }\end{array}$} & & \multicolumn{5}{|c|}{ Risk severity } \\
\hline & & 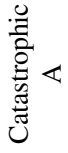 & 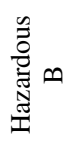 & $\cdot \frac{\bar{\sigma}}{\bar{z}}$ & $\stackrel{\overrightarrow{0}}{\Xi}$ & $\begin{array}{l}\frac{0}{0} \\
\frac{000}{00} \\
0 \\
0 \\
0\end{array}$ \\
\hline Frequent & 5 & $5 \mathrm{~A}$ & $5 B$ & $5 \mathrm{C}$ & $5 \mathrm{D}$ & $5 \mathrm{E}$ \\
\hline Occasional & 4 & $4 \mathrm{~A}$ & $4 \mathrm{~B}$ & $4 \mathrm{C}$ & $4 \mathrm{D}$ & $4 \mathrm{E}$ \\
\hline Remote & 3 & $3 \mathrm{~A}$ & $3 \mathrm{~B}$ & $3 \mathrm{C}$ & $3 \mathrm{D}$ & $3 \mathrm{E}$ \\
\hline Improbable & 2 & $2 \mathrm{~A}$ & $2 \mathrm{~B}$ & $2 \mathrm{C}$ & $2 \mathrm{D}$ & $2 \mathrm{E}$ \\
\hline $\begin{array}{l}\text { Extremely } \\
\text { improbable }\end{array}$ & 1 & $1 \mathrm{~A}$ & 1B & $1 \mathrm{C}$ & $1 \mathrm{D}$ & $1 \mathrm{E}$ \\
\hline
\end{tabular}

There was 557 reported events between 2008 and 2016 caused by all engine types installed on Polish registered aircraft.

Figure 1 shows an annual number of reported aviation events caused by powerplant types considered in this article.

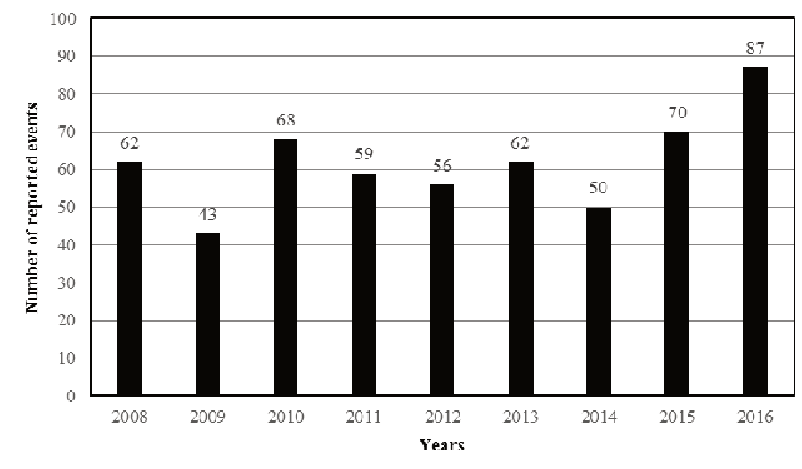

Fig. 1. Number of reported aviation events caused by powerplants installed on Polish registered aircraft

Figure 2 shows changes of the coefficient $K_{1000}$ for aviation events occurred within 2008-2016, for all powerplant types. The below presented figures are showing increased trend of the reported aviation occurences per 1000 registered aircraft for last two years. Such a situation 
is different considering various engine types. Next four chapters contains detailed information of aviation events have occurred for each of the powerplant type since 2008 .

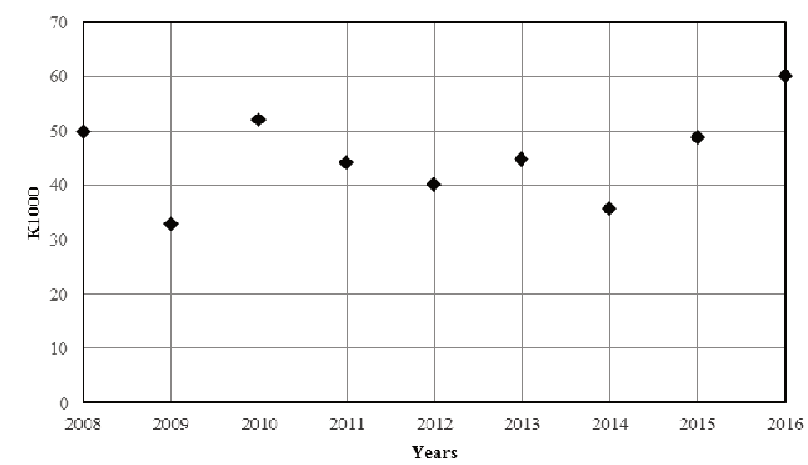

Fig. 2. Changes of the coefficient K1000 for SCF-PP aviation occurrence categories

\section{Aviation piston engines}

Piston engines will be a suitable and popular engine choice among personal airplane owners for many years. From a manufacturing and engineering perspective, the reciprocating engines found in piston aircraft are far less complex than turboprops. Piston aircraft are generally smaller aircraft, seating no more than six passengers, and are well suited for relatively short missions of 500 kilometers or less. There are many piston engine models being currently in operation in Poland. All of them are installed on aircraft which are operated in general aviation. Tab. 4 contains information about numbers of each installed engine model.

Table 4. Model and number of the piston engines

\begin{tabular}{|l|c|}
\hline \multicolumn{1}{|c|}{ Engine model } & Number of installed engines \\
\hline Austro Engine & 5 \\
\hline Bombardier Rotax & 101 \\
\hline Continental & 208 \\
\hline de Havilland Gipsy Major & 3 \\
\hline Franklin & 23 \\
\hline Jabiru & 2 \\
\hline Limbach & 4 \\
\hline LOM & 46 \\
\hline Lycoming & 492 \\
\hline PZL Kalisz ASZ62 & 120 \\
\hline PZL Kalisz AI14 & 94 \\
\hline PZL Kalisz M11 & 7 \\
\hline PZL Kalisz WN3 & 3 \\
\hline Rolls Royce & 20 \\
\hline Rotor Way RI & 4 \\
\hline Simonini Victor & 1 \\
\hline Subaru EA & 4 \\
\hline Thielert TAE125-01 Centurion 1.7 & 7 \\
\hline Titan CC340 & 4 \\
\hline Vedeneyev M14 P & 35 \\
\hline Verner 1400 & 1 \\
\hline Volkswagen 1600 & 1 \\
\hline Walter Mikron III & 3 \\
\hline WSK PZL Rzeszów PZL3 SR & 1 \\
\hline Total & \\
\hline
\end{tabular}

Figure 3 shows view of the contemporary utilized typical aviation piston engine with description of its main parts [3].

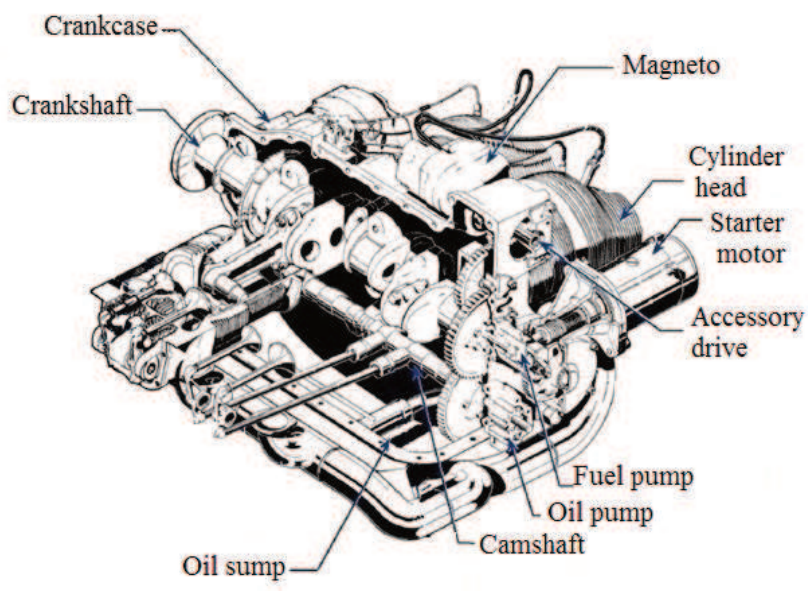

Fig. 3. Four cylinders, horizontally opposed, air cooled aviation piston engine

\subsection{General information}

There was totally 207 aviation events caused by piston engines in 2008-2016. Due to the fact that almost $95 \%$ of the piston engines powered aircraft are single engine airplane each failure is not the only a threat to the flying crew safety, but most importantly for individuals on the ground.

Figure 4 shows an annual number of reported aviation events caused by piston engines. Figure 5 shows changes of the coefficient $\mathrm{K}_{1000 \text { pist }}$. between 2008-2016.

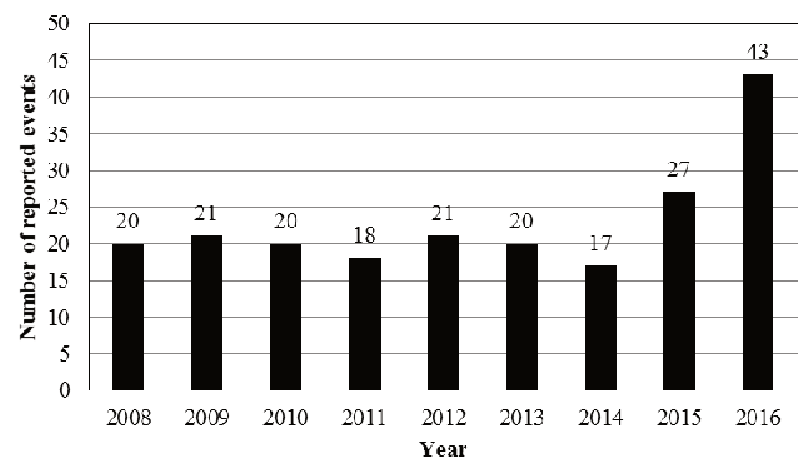

Fig. 4. Number of events caused by piston engines installed on Polish registered aircraft between 2008-2016

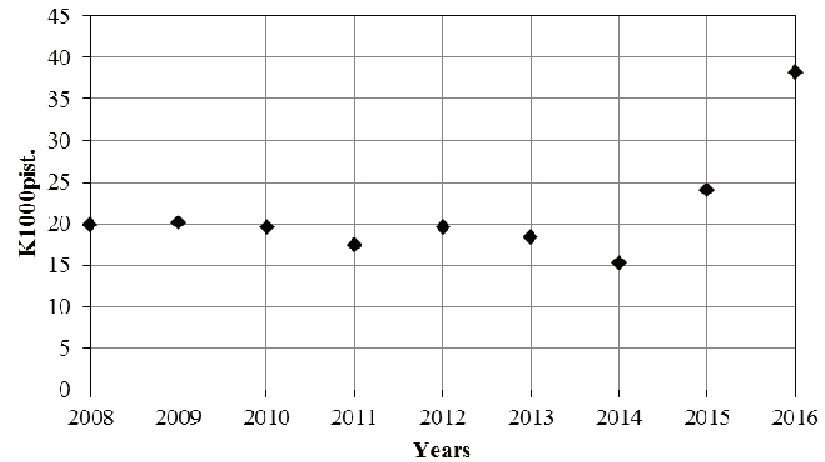

Fig. 5. Changes of the coefficient $\mathrm{K}_{1000 \text { pist. }}$

It has to be pointed out that for last two years sudden, significant increase in number of events caused by this 
engine type is observed. From 17 in 2014 to 43 in $2016-$ more than twice.

Figure 6 gives (in percent) information during which aircraft maneuver and how often reported event caused by piston engine took place in 2008-2016. It is unacceptable that the vast amount of the powerplant reported failures occurred during aircraft movement. Only $15 \%$ of them were detected during routine maintenance tasks.

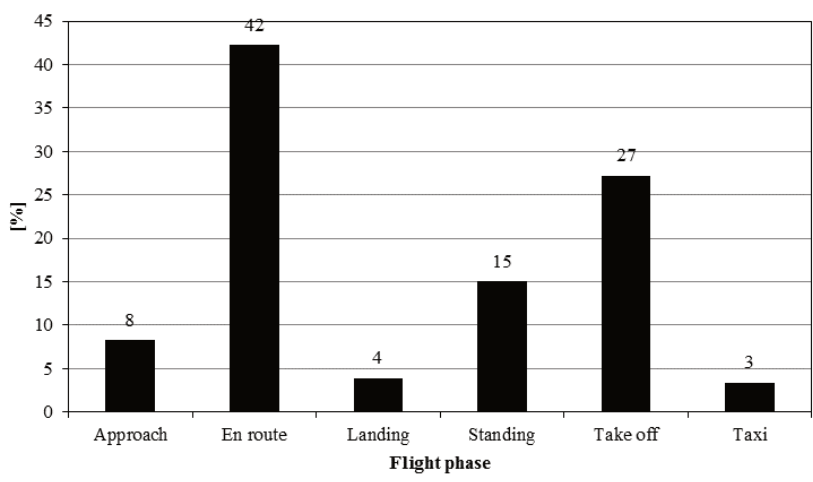

Fig. 6. Flight phases share when piston engine malfunction took place

Figure 7 shows reported system defects frequency in percent assigned to the certain ATA chapter for the piston engines in the 2008-2016.

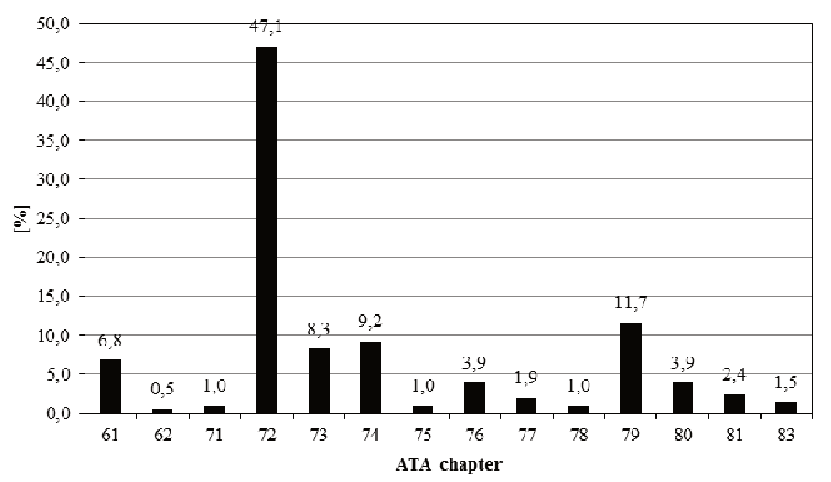

Fig. 7. Share of each powerplant system events coded by ATA 100 chapter between 2008 and 2016

The above Fig. 7 shows "share" of the certain ATA chapter in percent in the total volume of the piston engines reported events. It was assumed that the most frequently occurred event - ATA chapter 72 has occurrence probability level equel 5. Next 79, 74 and 73 level 4, 61 level 3, 76 and 80 level 2 and the remaining 62, 71, 75, 77, 78,81 and 83 level 1 . According to the methodology described in the introduction (Tab. 1, Tab. 2 and Tab. 3) to each from the above ATA chapters safety risk severity was assigned, based on events consequences described in the ECCAIRS reports. Then safety risk assessment matrix was developed for piston engines operated in Poland. Results of the analysis are presented in the Tab. 5 .

Every item presented in the red field requires immediate actions, which have to be taken on the country level in order to mitigate safety risk connected with the highlted in red engine systems coded in ATA 72, 74 and 79 chapters. Engine systems marked in yellow are acceptable based on risk (moderate risk) mitigation. However, a schedule for performance of safety assessment has to be prepared in order to find ways to bring down safety risk to low. In this way aviation authority can develop or order program implementation of safety risk mitigation, in our case on Country level. Below are discussed in details "red" ATA chapters.

Table 5. Safety risk assessment matrix for piston engine systems

\begin{tabular}{|c|l|c|}
\hline \multicolumn{2}{|c|}{ ATA chapter } & \multirow{2}{*}{ Index } \\
\hline No. & \multicolumn{1}{|c|}{ Contents } & $3 \mathrm{C}$ \\
\hline 61 & Propellers/propulsors & $1 \mathrm{D}$ \\
\hline 62 & Main rotor(s) & $1 \mathrm{C}$ \\
\hline 71 & Powerplant general & $5 \mathrm{~B}$ \\
\hline 72 & Engine-reciprocating & $4 \mathrm{C}$ \\
\hline 73 & Engine-fuel and control & $4 \mathrm{~B}$ \\
\hline 74 & Ignition & $1 \mathrm{E}$ \\
\hline 75 & Bleed air & $2 \mathrm{C}$ \\
\hline 76 & Engine controls & $1 \mathrm{C}$ \\
\hline 77 & Engine indicating & $1 \mathrm{E}$ \\
\hline 78 & Exhaust & $4 \mathrm{~B}$ \\
\hline 79 & Oil & $2 \mathrm{D}$ \\
\hline 80 & Starting & $1 \mathrm{E}$ \\
\hline 81 & Turbines & $1 \mathrm{D}$ \\
\hline 83 & Accessory gear boxes \\
\hline
\end{tabular}

\subsection{ATA chapter 72}

There were 97 reported aviation events in the ATA 72 chapter between 2008-2016. Figure 8 shows an annual number of reported events as a result of piston engine failures coded in that chapter.

Figure 9 gives (in percent) information during which aircraft maneuver and how often failure of the piston engine in the ATA 72 chapter took place between 2008-2016.

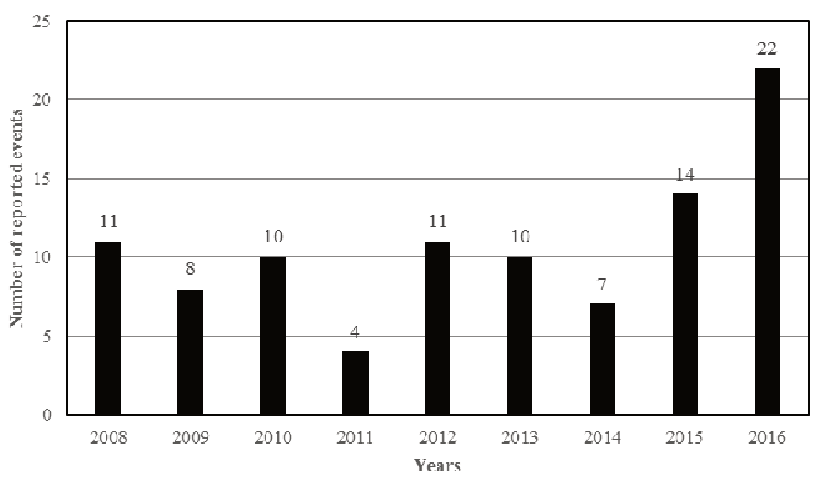

Fig. 8. Number of events caused by piston engines installed on Polish registered aircraft in the ATA 72 chapter between 2008-2016

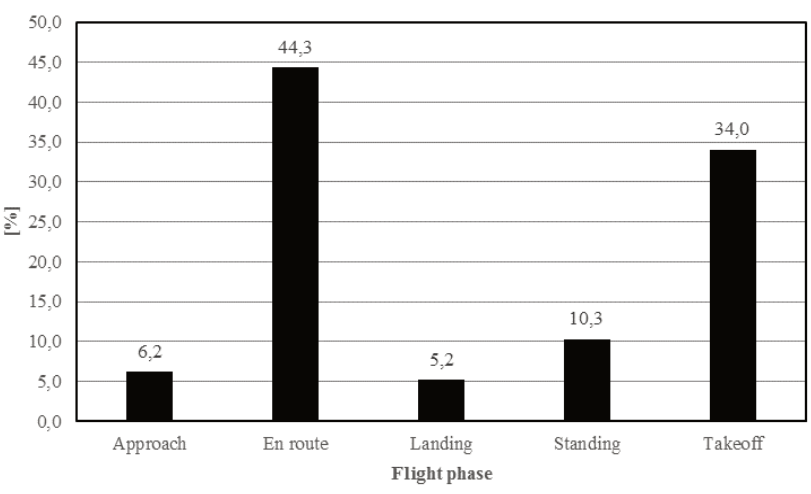

Fig. 9. Flight phases share when powerplant malfunction ATA chapter 72 took place 
Majority failures concern ATA sub charters 72-20-00 power section and 72-30-00 cylinder section. As a result of the engine failure serious events took place. Table 6 shows in numbers result of the piston engines malfunction, symptoms observed and precursors of the powerplant defect, where it was confirmed.

Almost 50\% out of the total (207) occurrences caused by powerplants can be assigned to the engine itself (see Fig. 7). Most of the events are connected with powertrain and cylinder systems. The events were caused by cracked exhaust valves. Also carbon deposit was observed on them. Other occurrences were caused by different failures of the cylinders. It can be presumed that those damages were mainly due to engines overheating that resulted from an improper exploitation.

\subsection{ATA chapter 74}

During 2008-2016 there was 19 events caused by ignition system. All of them in the two ATA subchapters 74-10-00 electrical power supply and 74-20-00 distribution. First includes magnetos, second spark plugs.

Figure 10 gives information during which aircraft maneuver a failure in the ATA 74 chapter took place within 2008-2016. The Tab. 7 shows in numbers result of the engine ignition system malfunctions, symptoms observed and precursors of the powerplant defects, where it was confirmed.

Spark plugs during post event checks were found with carbon deposit, few wrongly fitted, which again is an evidence of careless maintenance or failure to meet engine exploitation procedures. More than $70 \%$ of ignition system malfunctions jeopardized flight safety as 13 aborted flights or emergency landings occurred.

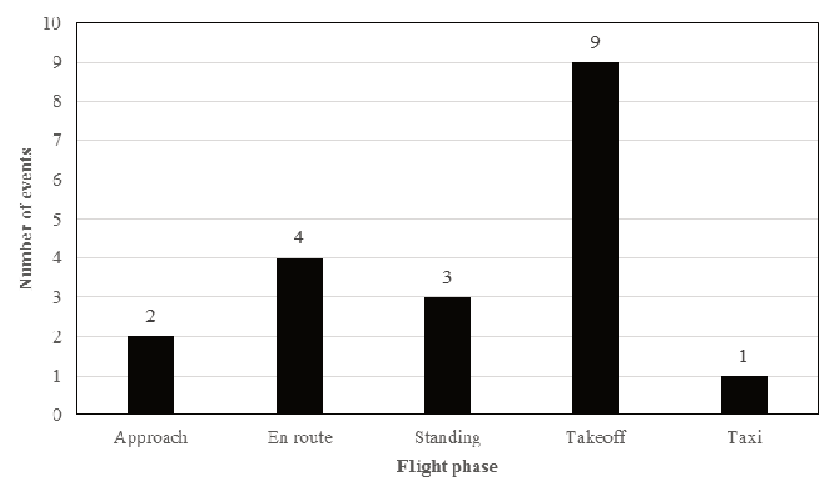

Fig. 10. Flight phases share when powerplant malfunction in the ATA 74 chapter took place

\subsection{ATA chapter 79}

Between 2008-2016 there was 23 events caused by engine oil system. Figure 11 gives information during which aircraft maneuver a failure coded in the ATA 79 chapter took place within 2008-2016.

The Tab. 8 shows in numbers result of the engine oil system malfunctions, symptoms observed and precursors of the powerplant defects, where it was confirmed.

Improperly installed or connected oil pipes causing leaks are the main, but not the only reason, for the reported events connected with the engine oil system. Most of them occurred due to maintenance imperfections. Oil system faults had a significant impact on flight safety. It needs to be mentioned that in 23 cases, in the years 2008-2016 out of the oil system malfunctions, 19 of them resulted in aborted flights or emergency landings.

Table 6. Confirmed roots of the piston engines failures coded in the ATA 72 chapter which caused aviation event

\begin{tabular}{|c|l|c|l|c|l|}
\hline No & Mulfunction result & No & Symptom & No & Confirmed precursor \\
\hline 14 & Emergency landing & 27 & Loss of power & 4 & Exhaust valve \\
\hline 51 & Aborted flight & 24 & Unstable engine work & 5 & Cylinder \\
\hline 3 & Aborted takeoff & 2 & Engine overheating & 5 & Crancase \\
\hline 2 & Ground roll stopped & 11 & In flight shut down & 4 & Crankshaft \\
\hline & & 1 & Engine vibration & 1 & Camshaft \\
\hline & & & 2 & Connecting rod \\
\hline
\end{tabular}

Table 7. Confirmed roots of the piston engines failures coded in the ATA 74 chapter which caused aviation event

\begin{tabular}{|c|l|c|l|c|l|}
\hline No & Mulfunction result & No & Symptom & No & Confirmed precursor \\
\hline 3 & Emergency landing & 8 & Unstable engine work & 10 & Spark plug \\
\hline 10 & Aborted flight & 4 & Loss of power & 5 & Magneto \\
\hline & & 2 & Engine vibration & 1 & Electrical wire \\
\hline
\end{tabular}

Table 8. Confirmed roots of the piston engines failures coded in the ATA 79 chapter which caused aviation event

\begin{tabular}{|c|l|c|l|c|l|}
\hline No & Mulfunction result & No & Symptom & No & Confirmed precursor \\
\hline 15 & Aborted flight & 3 & Loss of power & 6 & Improper maintenance \\
\hline 4 & Emergency landing & 4 & Oil pressure low & 6 & $\begin{array}{l}\text { Metal chips in the oil filter or on } \\
\text { detector }\end{array}$ \\
\hline 1 & Ground roll stopped & 3 & Oil temperature high & & \\
\hline 1 & Aircraft elements damage & 2 & Engine vibration & & \\
\hline & & 1 & Oil pressure high & & \\
\hline & & 3 & Oil leak & & \\
\hline & & 1 & Not extended nose gear & & \\
\hline & & 1 & Oil chip indication & & \\
\hline
\end{tabular}




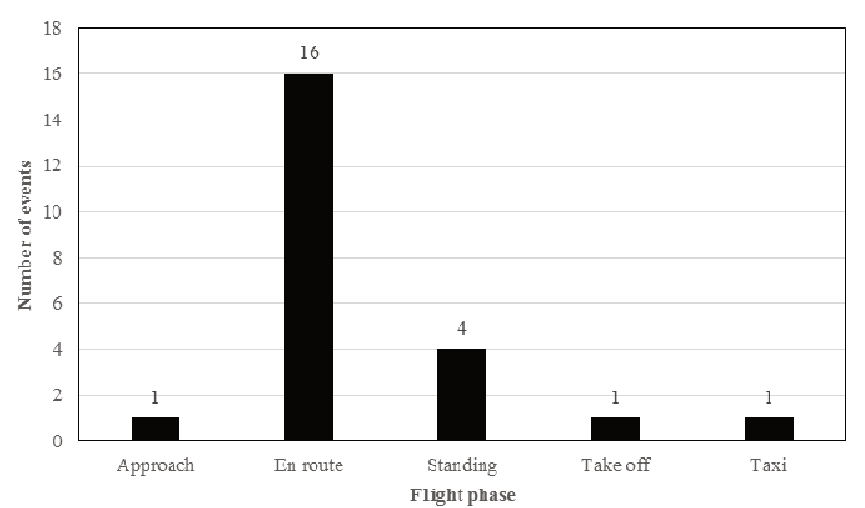

Fig. 11. Flight phases share when powerplant malfunction in the ATA 79 chapter took place

The above descriptions presented leading to the conclusion that piston engines require changes in the current exploitation system in order to improve flight safety. In addition to the existing maintenance and operational requirements already included in the manufacturers' manuals such a system should introduce new tasks like, for example, engine vibration or flight parameters monitoring. It seems that also more insightful supervision of the maintenance tasks execution as well as way of flying is required. This will not have only a positive economic impact for general aviation operators, but also intangible, like improvement of the flight safety, technical culture and sense of responsibility of aviation technical staff and pilots.

\section{Turboprop engines}

Turboprop engines are source of power for aircraft operated in general and commercial aviation. Turboprop aircraft are generally most efficient at altitudes of 6000 to 9000 meters and at average speeds of $450 \mathrm{~km} / \mathrm{h}$ to 600 $\mathrm{km} / \mathrm{h}$. Turboprops tend to be larger than piston aircraft with greater passenger capacity - and more fuel on-board - and are more likely to be found flying distances of up to 2000 $\mathrm{km}$. It seems that turboprops will be used widely for a long time, both short and medium distances. Table 9 presents number of installed turboprop engine models on Polish registered aircraft.

Today's turboprop engines are characterized by a huge power range (300-11000 $\mathrm{kW}$ ) and a variety of design forms. These are now mostly single-rotor with axial or axial compressors with a radial stage, and a large share (among small and medium power engines) of separate power turbines.

Table 9. Model and number of the turboprop engines

\begin{tabular}{|l|c|}
\hline \multicolumn{1}{|c|}{ Engine model } & $\begin{array}{c}\text { Number of installed } \\
\text { engines }\end{array}$ \\
\hline PRATT AND WHITNEY PT6A FAMILY & 53 \\
\hline PRATT AND WHITNEY PW 150 & 20 \\
\hline PRATT AND WHITNEY PW 124 & 10 \\
\hline GENERAL ELECTRIC CT7 5A2 & 28 \\
\hline HONEYWELL TPE331 & 3 \\
\hline IVCHENKO AI24 VT & 4 \\
\hline LOM M601 E & 4 \\
\hline Total & $\mathbf{1 2 2}$ \\
\hline
\end{tabular}

Figure 12 shows scheme of the contemporary utilized popular Pratt \&Whitney PT6 turboprop engine with description of its main parts, covering the power range between 430 and 680 shaft kilowatts [8, 9].

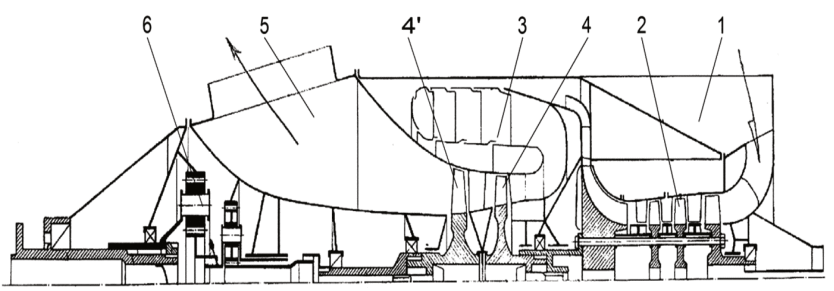

Fig. 12. Design scheme of PT6 turboprop engine: 1 - air inlet, 2 - compressor, 3 - combustor chamber, 4 - compressor powered turbine, 4' power turbine 5 - exhaust, 6 - reduction gearbox

\subsection{General information}

There were 101 aviation events caused by turboprop engine malfunction. It has to be emphasized that in Poland almost $95 \%$ of turbo-propops are twin engines aircraft, so results of a powerplant failure are not so dangerous like for single engine aircraft.

Figure 13 shows an annual number of reported aviation events caused by turboprop engines. Figure 14 shows changes of the coefficient $\mathrm{K}_{1000 \text { tprop }}$ during 2008-2016.

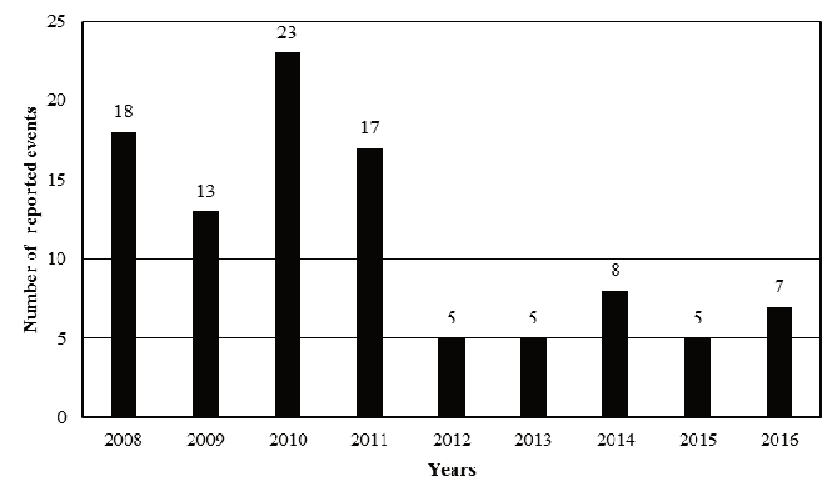

Fig. 13. Number of events caused by turboprop engines installed on Polish registered aircraft between 2008-2016

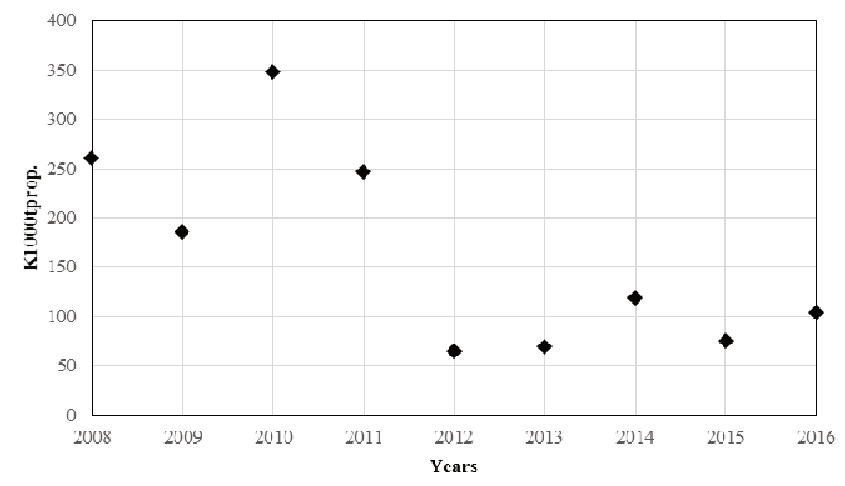

Fig. 14. Changes of the coefficient $\mathrm{K}_{1000 t p r o p}$

Above pictures are showing sudden decrease in number of events as well as coefficient $\mathrm{K}_{1000 \text { tprop }}$ from 2012 without turboprop aircraft fleet size changes. Reason for such level of safety increase is one of the operators aircraft fleet a 
change to another turboprop aircraft type powered by different engine model.

Figure 15 shows reported system defects frequency in percent assigned to the certain ATA chapter for the turboprop engines in the years 2008-2016. Figure 16 gives (in percent) information during which aircraft maneuver and how often reported event caused by turboprop engine took place within 2008-2016.

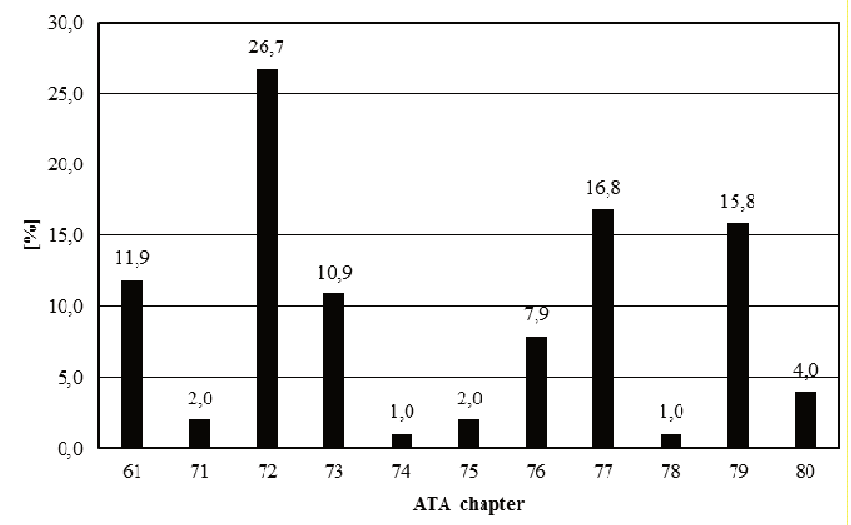

Fig. 15. Share of each powerplant system events coded in the ATA 100 chapter between 2008 and 2016

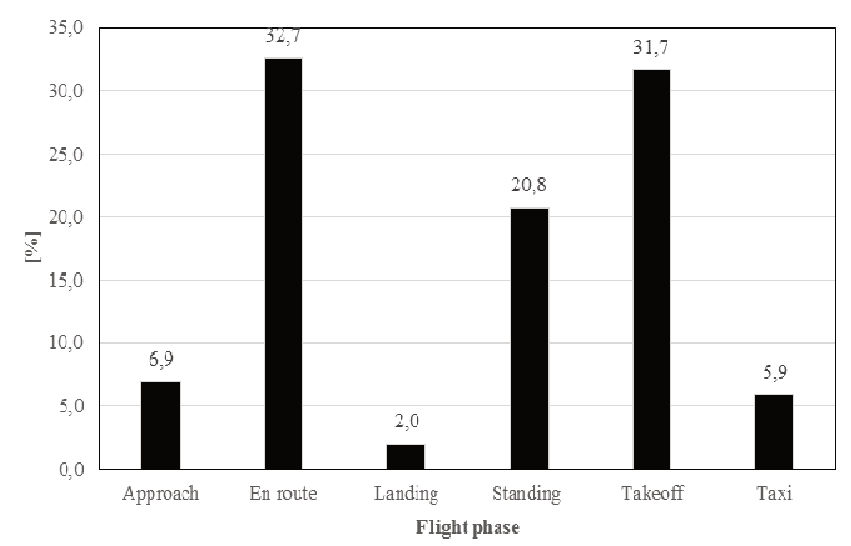

Fig. 16. Flight phases share when powerplant caused event took place

Figure 15 shows in percent "share" of the certain ATA chapter in the total volume of the turboprop engines reported events. It was assumed that the most frequently occurred event - ATA chapter 72 has occurrence probability level equel 5. Next, 77 and 79 level 4, 61, 73, 76 level 3, 80 level 2 and the remaining 71, 74, 75, 78, level 1. According to the methodology described in the Introduction
(Tab. 1, Tab. 2 and Tab. 3) to each from the above ATA chapters safety risk severity was assigned, based on events consequences described in the ECCAIRS reports.

Then safety risk assessment matrix was developed for turboprop engines operated in Poland. Results of the analysis are presented in the Tab. 10.

Table 10. Safety risk assessment matrix for turboprop engine systems

\begin{tabular}{|c|l|c|}
\hline \multicolumn{2}{|c|}{ ATA chapter } & \multirow{2}{*}{ Index } \\
\hline No. & \multicolumn{1}{|c|}{ Contents } & $3 \mathrm{D}$ \\
\hline 61 & Propellers/propulsors & $1 \mathrm{E}$ \\
\hline 71 & Powerplant general & $5 \mathrm{D}$ \\
\hline 72 & Engine & $3 \mathrm{D}$ \\
\hline 73 & Engine-fuel and control & $1 \mathrm{E}$ \\
\hline 74 & Ignition & $1 \mathrm{E}$ \\
\hline 75 & Bleed air & $3 \mathrm{D}$ \\
\hline 76 & Engine controls & $4 \mathrm{D}$ \\
\hline 77 & Engine indicating & $1 \mathrm{E}$ \\
\hline 78 & Exhaust & $4 \mathrm{C}$ \\
\hline 79 & Oil & $2 \mathrm{E}$ \\
\hline 80 & Starting & \\
\hline
\end{tabular}

Similarly like for piston engines, turboprops systems marked in yellow are acceptable based on risk (moderate risk) mitigation. However, a schedule for performance of safety assessment has to be prepared in order to find ways to bring down safety risk to low. Especially when so many engine systems fall in moderate risk level. The Tab. 11 shows in numbers result of the turboprops system malfunctions, symptoms observed and precursors of the powerplant defects, where it was confirmed.

Turboprops failures, which caused aviation events were mainly due to medium level of engine parts reliability and durability. There were only seven confirmed maintenance faults.

\section{Turboshaft engines}

There are 135 helicopters powered by turboshaft engines registered in Poland. Fourteen of them are in MTOM $>5700 \mathrm{~kg}$ class. Most of them is powered by engines models like: Allison 250C20, different kinds of P\&W 206, Turbomeca Arrius 2F and Arriel 2B1. Also manufactured in Poland PZL-10W and GTD-350 are being in exploitation.

Mainly twin engine helicopters are utilized. Tab. 12 presents number of installed turboprop engine models on Polish registered helicopters.

With the constant number of helicopters, the number of events reported to the ECCAIRS database have increased since 2008 (Fig. 18), as a consequence also coefficient $\mathrm{K}_{1000 \text { tshaft }}$, proportionally has increased (Fig. 19).

Table 11. Confirmed roots of the turboprop engines failures which caused aviation event

\begin{tabular}{|c|c|c|c|c|c|}
\hline No & Mulfunction result & No & Symptom & No & Confirmed precursor \\
\hline 25 & Aborted flight & 12 & In flight shut down & 6 & Auto feather unit/governor \\
\hline 19 & Aborted takeoff & 12 & Unstable engine work & 4 & Starter generator \\
\hline 4 & Ground roll stopped & 5 & Low oil pressure & 5 & Torque indication \\
\hline \multirow[t]{5}{*}{6} & Emergency landing & 1 & High oil pressure & 4 & EGT indication \\
\hline & & 2 & Engine vibration & 7 & Wrong seals/tubes installation \\
\hline & & & & 6 & PCU/HMU/EEC failure \\
\hline & & & & 3 & Compressor blades damage \\
\hline & & & & 1 & Turbine blade damage \\
\hline
\end{tabular}



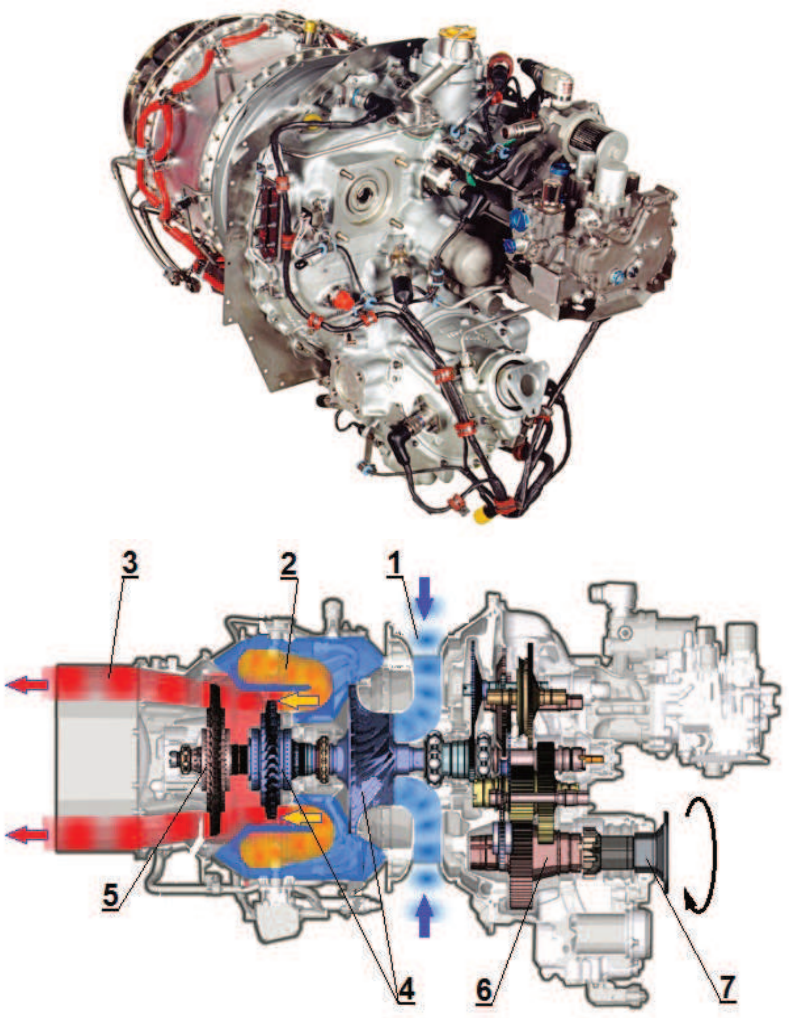

Fig. 17. View and cross-section of the PW 206 turboshaft engine: 1 - air inlet, 2 - combustor chamber, 2 - compressor, 3 - exhaust, 4 - radial compressor and turbine, 6 - reduction gearbox, 7 - shaft [17]

Table 12. Model and number of the turboshaft powerplants

\begin{tabular}{|l|l|c|}
\hline \multicolumn{1}{|c|}{ Engine model } & \multicolumn{1}{c|}{ Helicopter type } & $\begin{array}{c}\text { Number } \\
\text { of helicopters }\end{array}$ \\
\hline PW 206 B2 & EC-135 & 25 \\
\hline GTD-350 & Mi-2 & 24 \\
\hline Turbomeca Arriel 2 B1 & EC-130 & 11 \\
\hline Turbomeca Arrius 2F & EC-120 & 11 \\
\hline PZL-10W & W-3 & 7 \\
\hline GE T-700 & S -70i & 6 \\
\hline Allison 250 C20B & Bell-206, Mi-2 Kania, & 5 \\
\hline Allison 250 C20R2 & H-369 & 5 \\
\hline Turbomeca Arriel 2 D & SW-4 & 4 \\
\hline PW 206 B3 & EC-135; EC-130 & 4 \\
\hline PW 207 D & Bell-427; Bell-429 & 4 \\
\hline R-R 300 & Robinson 66 & 4 \\
\hline Allison 250 C47B & Bell-427 & 4 \\
\hline
\end{tabular}

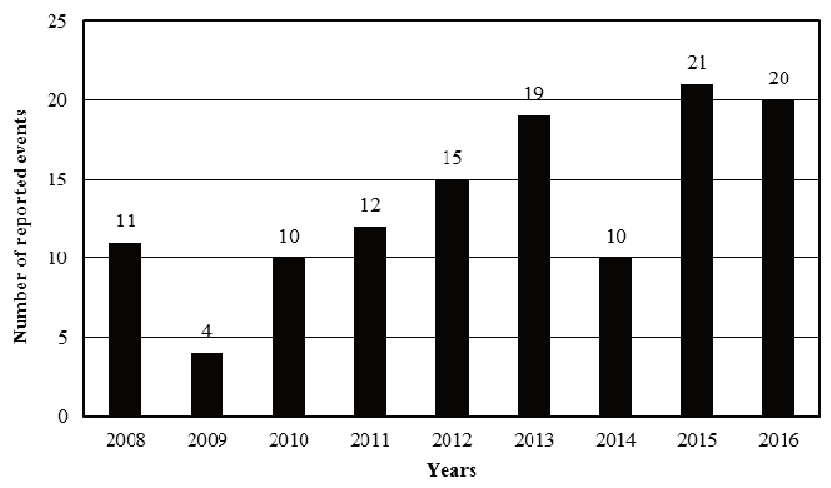

Fig. 18. Number of events caused by turboshaft engines installed on Polish registered aircraft between 2008-2016

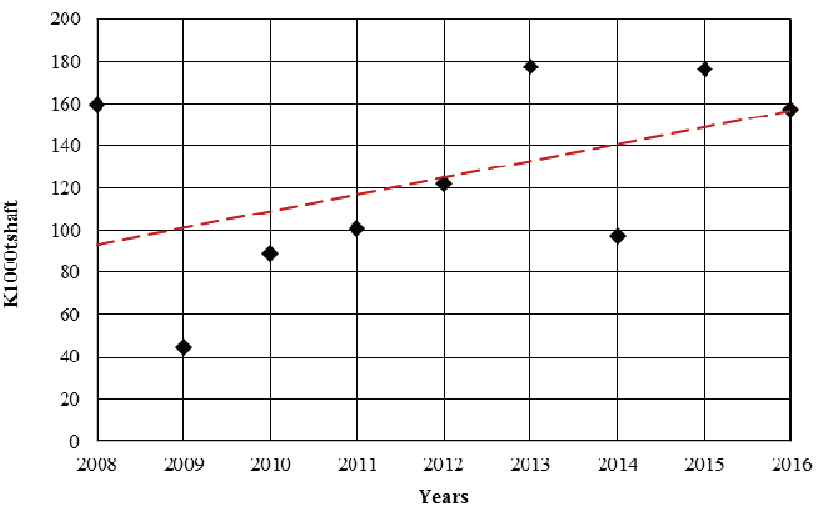

Fig. 19. Changes of the coefficient $\mathrm{K}_{1000 \text { tshaft }}$ and the trend line

A more accurate analyzes of the events shows that most of them concerns engine oil system (ATA 79 chapter) and ATA 72 chapter. This order is preserved both in terms of number of events and percentage share (see Fig. 20 and 21).

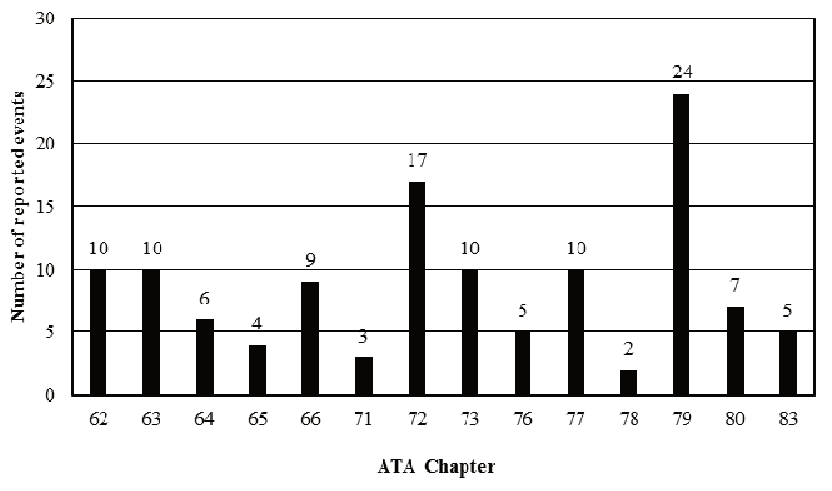

Fig. 20. Number of the turboshaft engine system events coded in ATA 100 chapter between 2008 and 2016

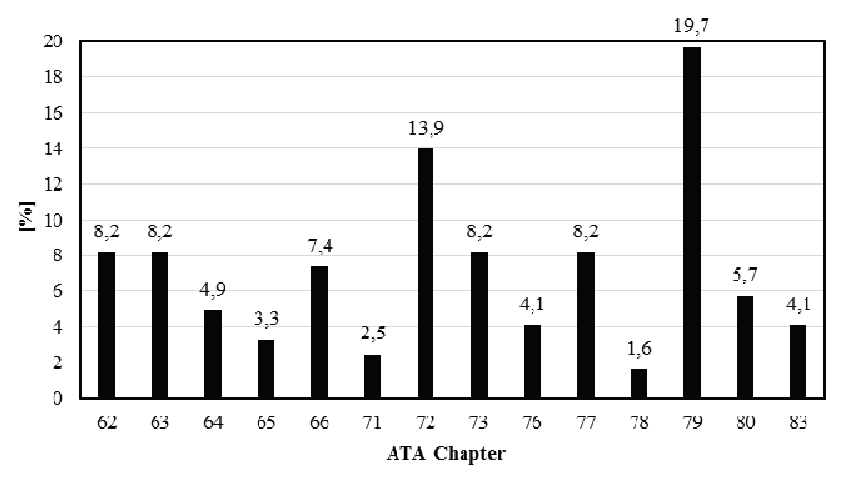

Fig. 21. Share of turboshaft engine system events coded in ATA 100 chapter between 2008 and 2016

The positive thing is that as many as $2 / 3$ of all turboshaft malfunctions were detected during routine maintenance checks and less than 1/5 during flight, which shows Fig. 22.

Using a method described in Chapter 2 (Tab. 1 and Tab. 2), a safety hazard assessment chart for turboshaft engines was developed (Tab. 13). It includes engine systems (coded according to ATA100) failures were mentioned in the incident reports. The most frequent failures are related to the oil system (ATA chapter 79), when malfunctions of the ex- 
haust system (ATA chapter 78) are rare. Oil system faults had a significant impact on flight safety. It needs to be mentioned that in the years 2008-2016 six of the oil system malfunctions ended in aborted mission, two emergency landings and one aborted takeoff. For helicopters that carry out rescue missions (HEMS), aborted flight may mean serious consequences for victims who may not be able to get medical help right away.

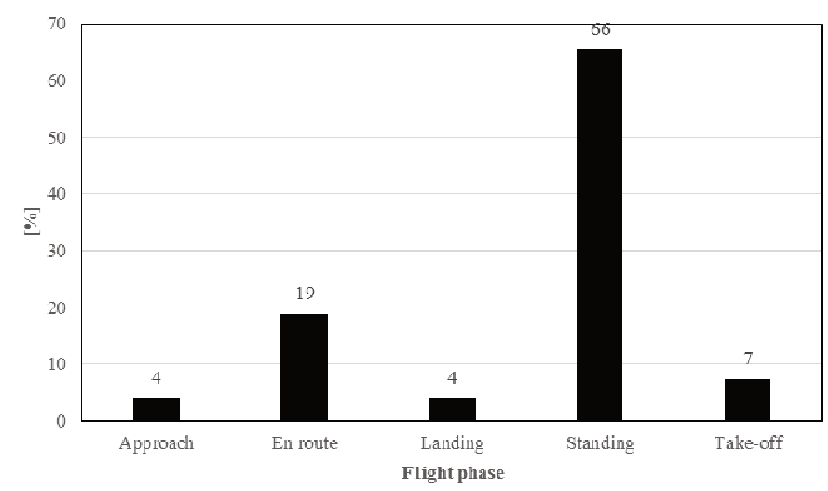

Fig. 22. Flight phases share when turboshaft engine malfunction took place

Even worse are the events related to the engine itself (ATA 72 chapter). In two cases, the sudden loss of power caused a catastrophe and complete destruction of the helicopters. Compressor surge has also been reported during startup at high ambient temperature. Also maximum torque exceedance in the drive transmission units, and a dozen or so cases of compressor blades damage by FOD hashappened. There have also been 3 cases of the rotor blades damage due to engine open covers or unplugged exhaust pipes.

Table 13. Safety risk assessment matrix for turboshaft engine systems

\begin{tabular}{|c|l|c|}
\hline \multicolumn{2}{|c|}{ ATA chapter } & \multirow{2}{*}{ Index } \\
\hline No & Contents & $3 \mathrm{D}$ \\
\hline 62 & Main rotors & $3 \mathrm{D}$ \\
\hline 63 & Main rotors (drive) & 2D \\
\hline 64 & Tail rotor & 2D \\
\hline 65 & Tail rotor (drive) & $3 \mathrm{C}$ \\
\hline 66 & Rotor blade and tail pylon folding & 1D \\
\hline 71 & Power plant general & 4C \\
\hline 72 & Engine & $3 \mathrm{C}$ \\
\hline 73 & Engine-fuel and control & 2D \\
\hline 76 & Engine controls & $3 \mathrm{C}$ \\
\hline 77 & Engine indicating & 1D \\
\hline 78 & Exhaust & 5D \\
\hline 79 & Oil & 3D \\
\hline 80 & Starting & 2D \\
\hline 83 & Accessory gear boxes (engine driven) & \\
\hline
\end{tabular}

Summary of the causes, symptoms and effects of major events involving turboshaft engines are contained in the Table 14. One of the most common causes are electrical wire connection breaks in the connectors. Electrical installations for helicopter engines operating at high vibration levels are particularly susceptible to the disconnection of contacts due to, for example, contamination by marine pollutants. At the same time, modern engine control systems cannot operate properly without rpm signal (FADEC turns off), as almost all control functions operate on this signal.

Ordinary occurrence for helicopter propulsion systems is the "oil chips" signal. In many cases it turns out that the chip detectors are so sensitive that they respond to the "dust" generated during the normal wear of the gears (even a case was reported of the piece of synthetic thread from the fabric detection). The causes of damage to the powerplants are also faults of the maintenance staff: improper assembly of components (gaskets, bolts), not closed engine covers (rush during dispatch).

\section{Turbojet engines}

Currently there are 94 Polish registered aircraft powered by jet engines, 80 of them fall into MTOM $>5700 \mathrm{~kg}$ class [16]. Details are shown in the Tab. 15. Figure 23 presents representative of the most popular worldwide turbofan engine family CFM56.
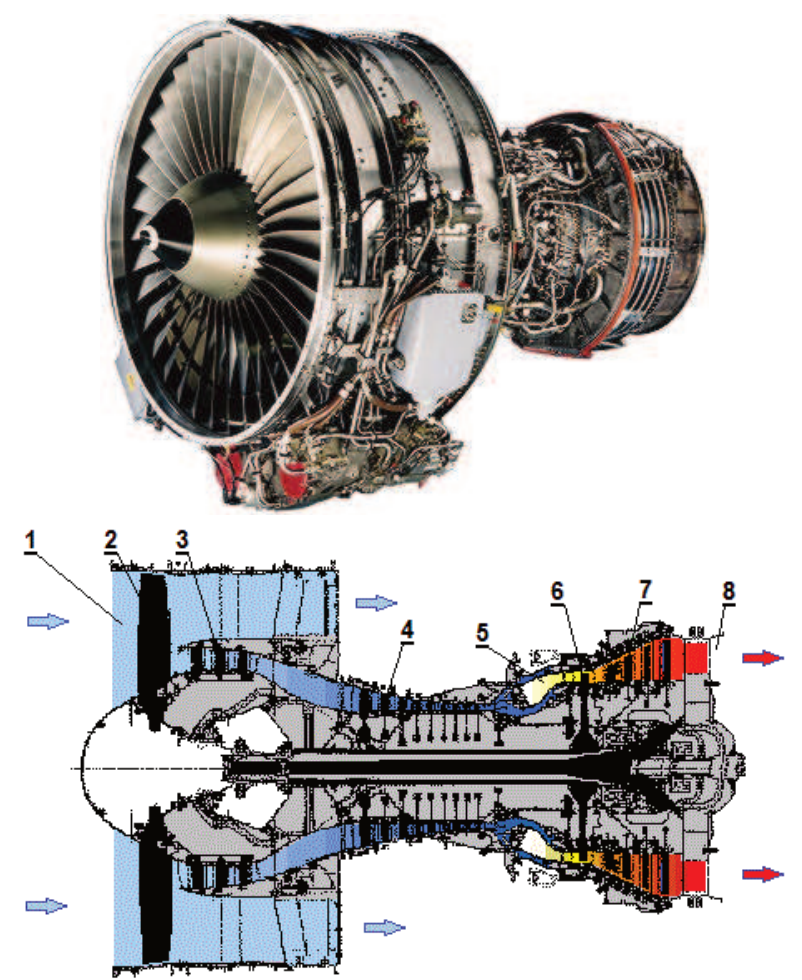

Fig. 23. Basic features of modern turbofan engine [18]: 1 - engine inlet, 2 - fan, external duct, 3 - low pressure compressor internal duct, 4 - high pressure compressor air, 5 - combustion chamber, 6 - high pressure turbine, 7 - low pressure turbine, 8 - exhaust

Table 14. Confirmed roots of the turboshaft engines failures which caused aviation event

\begin{tabular}{|c|l|c|l|l|l|}
\hline No & \multicolumn{1}{|c|}{ Mulfunction result } & No & \multicolumn{1}{|c|}{ Symptom } & No & \multicolumn{1}{c|}{ Confirmed precursor } \\
\hline 13 & Aborted flight & 7 & Engine chips & 20 & Main gearbox tapping \\
\hline 10 & Emergency landing & 6 & Unstable engine work & 21 & Electrical connection missing \\
\hline 3 & Aborted take off & 5 & In flight shut down & 12 & Foreign object damage \\
\hline & & 3 & Oil pressure or temperature & 7 & Incorrect bolt/gaskets installation \\
\hline & & 3 & FADEC fail & & \\
\hline
\end{tabular}


The aircraft jet propulsion usually consists of two engines placed under the aircraft wings or at the rear of the fuselage. Currently on Polish registered aircraft mostly turbofan engines are installed. They have superior fuel efficiency over single shaft engines, which are only used in military applications on aircraft of the 50's.

Table 15. Type and number of the aircraft powered by jet turbine powerplants

\begin{tabular}{|l|l|c|}
\hline \multicolumn{1}{|c|}{ Engine model } & \multicolumn{1}{|c|}{ Aircraft type } & $\begin{array}{c}\text { Number } \\
\text { of aircraft }\end{array}$ \\
\hline GE CF-34 & $\begin{array}{l}\text { Embraer } \\
\text { ERJ 170 and 190 }\end{array}$ & 26 \\
\hline CFM-56 serie 3, 5 and 7 & $\begin{array}{l}\text { Boeing 737 and Airbus } \\
321\end{array}$ & 24 \\
\hline PW serie 300, 500 and 600 & $\begin{array}{l}\text { Cessna 510 } \\
\text { Embraer 500 } \\
\text { Falcon 2000 } \\
\text { Learjet 60 }\end{array}$ & 8 \\
\hline IAE V2527 & Airbus 320 & 6 \\
\hline Trent 1000 & Boeing 787 & 6 \\
\hline Williams FJ44 & $\begin{array}{l}\text { Cessna 525 } \\
\text { Beech 390 } \\
\text { Raytheon 390 }\end{array}$ & 6 \\
\hline Allison AE3007 & $\begin{array}{l}\text { Embraer } \\
\text { EMB 135 and 145 }\end{array}$ & 5 \\
\hline Honeywell AS907 & Bombardier 100 & 4 \\
\hline Honeywell TFE731 & $\begin{array}{l}\text { Gulfstream 150 } \\
\text { Learjet 45 } \\
\text { Hawker 750 }\end{array}$ & 3 \\
\hline
\end{tabular}

Number of reported events as well as factor $\mathrm{K}_{1000 \mathrm{jet}}$ since 2011 have stabilized (Fig. 24 and 25).

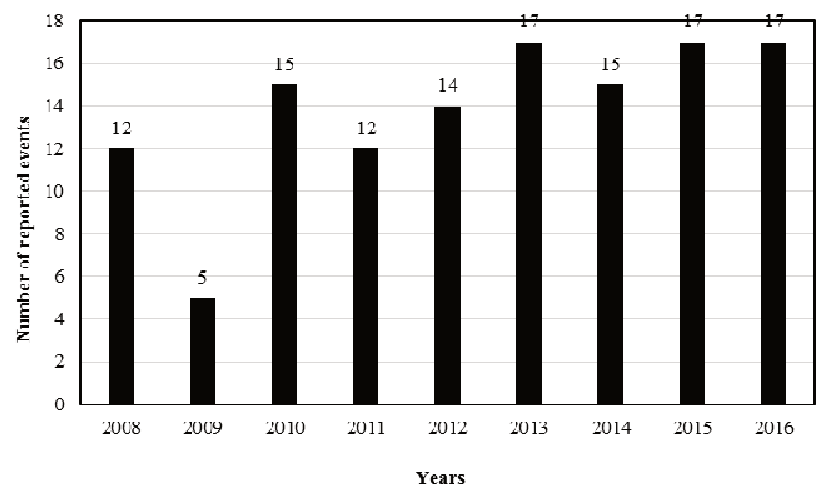

Fig. 24. Number of events caused by turbojet engines installed on Polish registered aircraft between 2008-2016

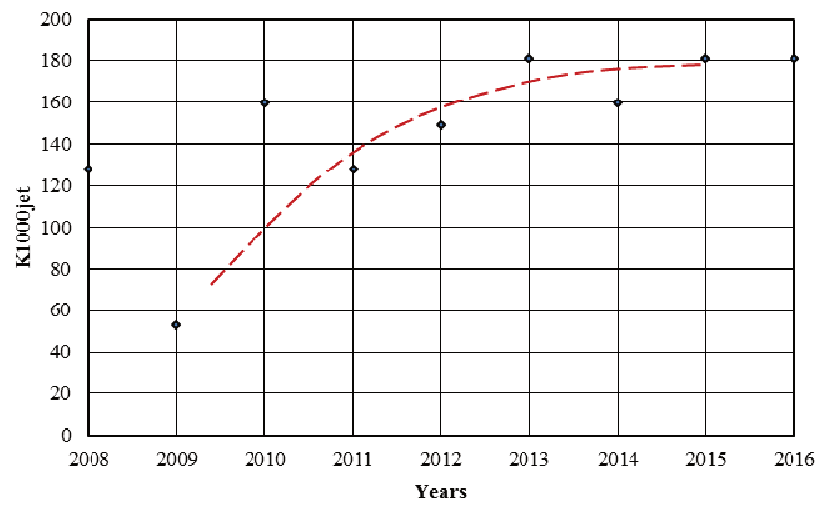

Fig. 25. Changes of the coefficient $\mathrm{K}_{1000 \mathrm{jet}}$ and the trend line
Figure 26 presents number of reported events in each ATA 100 chapter dedicated to powerplant systems. Fig. 27 shows reported system defects frequency in percent assigned to the certain ATA chapter for the turbojet engines in the years 2008-2016. Fig. 28 gives (in percent) information during which aircraft maneuver and how often reported event caused by turbojet engine took place between 2008-2016.

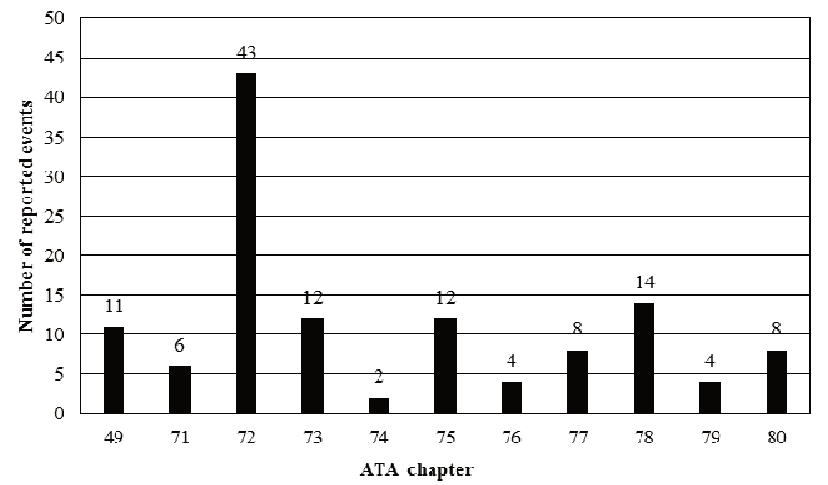

Fig. 26. Number of the turbojet engine system events coded by ATA 100 chapter between 2008 and 2016

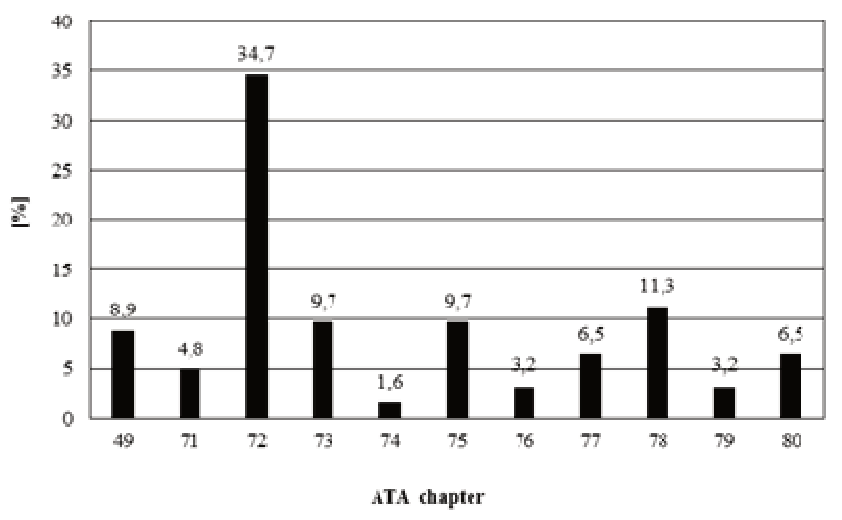

Fig. 27. Share of turbojet engine system events coded by ATA 100 chapter between 2008 and 2016

Figure 27 shows "share" of the certain ATA chapter in percent in the total volume of the turbojet engines reported events. It was assumed that the most frequently occurred event concerns engine design parts coded in ATA chapter 72 , next are events in the ATA chapters 78, 75 and 73. The most serious consequences are caused by events related to the engine itself (chapter ATA 72). In 43 cases, 10 ended with aborted flight, 4 aborted takeoffs and 1 emergency landing. The reason was usually the sudden increase in engine vibration, compressor surge, also exhaust temperature limit exceedances, and thrust differences between engines causing the aircraft drift during takeoff. Borescope inspections performed during routine maintenance detected damage to the fan blades and compressor blades caused by foreign objects (FOD).

Failures of the exhaust (ATA chapter 78) caused aborted takeoff ( 5 out of 14 events). One aborted flight and one emergency landing took place. During routine maintenance checks usually thrust reverser sensors mulfunction were reported. 
Problems with the fuel flow are very important for flight safety as this is the main parameter of the engine control. In the fuel flow control system (ATA chapter 73), clogged filters ( 5 out of 12 cases) or fuel pump failures ( 3 cases) were an events reason.

Malfunctions of the engine bleed system (75 ATA chapter) are most likely due to incorrect operation of the control valves. The inability to open such a valve results in, for example, the failure of the de-icing installation or the cabin pressurization system. Leakage of this valve causes that hot air flows into the engine nacelle and, for example, activates a fire alarm. A relatively common cause of malfunction of several airframe systems is the jamming of the valve that opens the air bleed from the compressor. This valve works in harsh conditions: the air temperature can exceed $400{ }^{\circ} \mathrm{C}$ and the pressure difference reaches dozens of bars.

It has to be taken into consideration for those involved in the SMS that more than $60 \%$ of the reported events have occured during different aircraft flight phases (Fig. 28). Some organizational projects has to be undertaken in order to increase failures detectability level during maintenance.

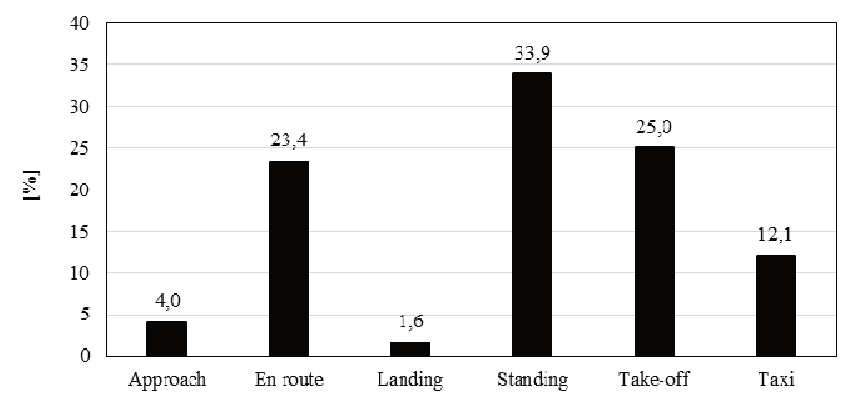

Fig. 28. Flight phase share when turbojet engine malfunction took place

Using a method described in Chapter 2 (Tab. 1 and Tab. 2), a safety hazard assessment chart for turbojet engines, similarly like for other engine types, was developed (Tab. 16). The most frequent failures are related to the engine itself (ATA chapter 72), when malfunctions of the ignition system (ATA chapter 74) are rare.

Similarly like for previusly analysed types of the engines, turbojet engine systems marked in yellow are acceptable based on risk (moderate risk) mitigation. The Tab. 17 shows in numbers result of the turbojets system malfunctions, symptoms observed and precursors of the powerplant defects, where it was confirmed.

Unfortunately there are also cases of service negligence. Quite a bizarre event was lack of one of the fuel filters on engines across one aircraft fleet. Other cases of this kind include improper mounting of the VSV mechanism resulting in damage to it, no connection between the actuator and the vane ring etc.

Table 16. Safety risk assessment matrix for jet engine systems

\begin{tabular}{|c|l|c|}
\hline \multicolumn{2}{|c|}{ ATA chapter } & \multirow{2}{*}{ Index } \\
\hline No & \multicolumn{1}{|c|}{ Contents } & $4 \mathrm{D}$ \\
\hline 49 & Airborne auxiliary power & $3 \mathrm{E}$ \\
\hline 71 & Power plant general & $5 \mathrm{D}$ \\
\hline 72 & Engine & $4 \mathrm{D}$ \\
\hline 73 & Engine-fuel and control & $1 \mathrm{E}$ \\
\hline 74 & Ignition & $4 \mathrm{C}$ \\
\hline 75 & Bleed air & $2 \mathrm{~B}$ \\
\hline 76 & Engine controls & $3 \mathrm{~B}$ \\
\hline 77 & Engine indicating & $4 \mathrm{D}$ \\
\hline 78 & Exhaust & $2 \mathrm{~B}$ \\
\hline 79 & Oil & $3 \mathrm{D}$ \\
\hline 80 & Starting & \\
\hline
\end{tabular}

\section{Conclusions}

The factors $\mathrm{K}_{1000 \mathrm{TYPE}}$ values, excluding piston engines are similar for all considered in the article powerplant types. They are in the range between 100 and 150 .

For piston engines, this value increased in 2016 and its value now is 60 . This is due to the relatively small number of reported events assigned to the number of airplanes. The reason for such situation is probably the lack of willingness to report all aviation occurrences by general aviation operators. Also, the number of notifications about engine defects, potentially threatening flight safety, found during maintenance inspections is disquietingly low for general aviation. This may indicate low quality level of the maintenance. Reasons for this situation require serious analyzes. Especially due to the fact that in general aviation mostly singleengine aircraft are operated.

The quality of the method described in the article can be improved by referring the number of events to the engine working hours. At present there is no flight hour data aggregated in one place. They are recorded in the aircraft technical logs. Also knowledge of the engine production dates would help in carrying out more accurate analyzes.

Table 17. Confirmed roots of the jet engines failures which caused aviation event

\begin{tabular}{|l|l|c|l|c|c|}
\hline No & \multicolumn{1}{|c|}{ Mulfunction result } & No & \multicolumn{1}{|c|}{ Symptom } & No & \multicolumn{1}{c|}{ Confirmed precursor } \\
\hline 24 & Aborted flight & 9 & Reverser disagree & Sensor damage \\
\hline 18 & Aborted taxi & 7 & EGT incorrect & 8 & Jamming out the air valve \\
\hline 15 & Aborted take off & 5 & Vibration too high & 4 & Foreign object damage \\
\hline 5 & Emergency landing & 5 & FADEC fail & & \\
\hline & & 7 & Fuel filter bypass or fuel \\
pressure too low & & \\
\hline
\end{tabular}

\section{Nomenclature}

ATA Air Transport Association

ECCAIRS European Coordination Center for Accident and Incident Reporting Systems

FADEC full authority digital engine control

SCF-PP system component failure - powerplant
SCAAI State Commission on Aircraft Accidents Investigation

SMS safety management system

VSV variable stator vanes

ULC Polish Civil Aviation Authority 


\section{Acknowledgments}

The work is financed from the Institute of Aviation statutory fund (Project no 21944).

\section{Bibliography}

[1] Aviation Occurrence Categories, Definitions and Usage Notes., International Civil Aviation Organization, Common Taxonomy Team, October 2013 (4.6).

[2] Annual Safety Review 2014, European Aviation Safety Agency, Safety Intelligence \& Performance Department, Cologne, Germany 2015.

[3] Aviation technician advanced training program Continental engine theory. 2005, Teledyne Continental Motors, Inc.

[4] ATA Specification 100 - Specification for Manufacturers' Technical Data, Publications Department Air Transport Association (ATA) of America, Inc. Washington, DC 200041707 USA.

[5] BALICKI, W., GŁOWACKI, P. Aircraft engines - analysis of reported systems failures in Polish Aviation during years 2008-2015. Journal of KONES Powertrain and Transport. 2016, 23(1), 31-37.

[6] BALICKI, W., GŁOWACKI, P., KAWALEC, M. Assessment of the airframe systems affecting safety risks caused by large aircraft. Journal of KONES Powertrain and Transport. 2016, 23(1), 39-46.

Paweł Głowacki, DEng. - Center of Space Technologies of the Institute of Aviation.

e-mail: Pawel.Glowacki@ilot.edu.pl
[7] BALICKI, W., GŁOWACKI, P., LOROCH, L. Safety performance indicators assessment for small aircraft airframe systems. Journal of KONES Powertrain and Transport. 2016, 23(2), 31-38.

[8] BOLIŃSKI, B., STELMASZCZYK, Z. Eksploatacja silników turbinowych. WKŁ, Warszawa 1981.

[9] CHEDA, W., MALSKI, M. Techniczny poradnik lotniczy. Silniki. WKE, Warszawa 1984.

[10] KEBA, I.W. Diagnostika aviacionnych gazoturbinnych dvigatieliej. Transport, Moskwa 1980.

[11] LEWITOWICZ, J. Podstawy eksploatacji statków powietrznych. T. 3. ITWL, Warszawa 2006.

[12] LOROCH, L. Bezpieczeństwo lotnictwa krajowego w działalności Instytutu Lotnictwa. „Bezpieczeństwo i niezawodność w lotnictwie. Rozwój lotnictwa w regionach”. NOT, Radom 2015.

[13] Safety Management Manual (SMM), Doc. 9859, AN/474, Third edition ICAO 2012.

[14] PETTIT, D., TURNBULL, A. General Aviation Aircraft reliability Study. NASA Langley Research Center, Hampton, Virginia 23681-2199, February 2001.

[15] WIŚNIOWSKI, W. XX lat programu samolotów lekkich i bezpieczeństwa (PSLiB). Transactions of the Institute of Aviation. 2014, 3(236)

[16] www.ULC.gov/pl/regulacja-rynku/3724-statystyki-wgportow-lotniczych.

[17] en.wikipedia.org/wiki/Pratt_\%26_Whitney_Canada_ PW200.

[18] www.cfmaeroengines.com/engines/cfm56/

Włodzimierz Balicki, DEng. - Center of Space Technologies of the Institute of Aviation.

e-mail: Wlodzimierz.Balicki@ilot.edu.pl 